\title{
Effects of resveratrol on vascular endothelial growth factor expression in osteosarcoma cells and cell proliferation
}

\author{
ZHONGHE LIU ${ }^{1}$, YANLAN LI ${ }^{2}$ and RUI YANG ${ }^{2}$ \\ ${ }^{1}$ Department of Orthopedics, First Affiliated Hospital of Xinxiang Medical University, Weihui, Henan 453100; \\ ${ }^{2}$ Department of Life Science and Technology, Xinxiang Medical University, Xinxiang, Henan 453003, P.R. China
}

Received May 8, 2012; Accepted July 16, 2012

DOI: $10.3892 / \mathrm{ol} .2012 .824$

\begin{abstract}
The aim of the current study was to investigate the effects of resveratrol (Res) on vascular endothelial growth factor (VEGF) expression and cell proliferation in the human osteosarcoma cell line U20S. U20S cells were treated with Res at various concentrations $(0,10,20$ and $40 \mu \mathrm{mol} / \mathrm{l})$ for various times $(24,48$ and $72 \mathrm{~h})$. The inhibitory effect of Res on U20S proliferation was observed using methyl thiazolyl tetrazolium (MTT) colorimetry. VEGF expression was determined using real-time polymerase chain reaction (RT-PCR) and western blot analysis. The inhibitory effect of Res on U20S proliferation increased as the concentration of Res increased. The inhibitory effect also increased with time. Res had an inhibitory effect on VEGF expression and significantly inhibited U20S cell proliferation. Res may exert an anti-osteosarcoma effect by inhibiting VEGF expression in tumor cells.
\end{abstract}

\section{Introduction}

Resveratrol (Res), chemically named 3,4',5-trihydroxystilbene, is a non-flavone polyphenolic compound which mainly exists in plants, including grapes, Veratrum nigrum and giant knotweed rhizome. It was first extracted from European Resveratrol (Res). Res, a type of phytoalexin, is extensively present in nature and is produced by plants under conditions of fungal infection, ultraviolet radiation or pathology. Res possesses multiple bioactivities, including antioxidation, antiinflammation, estrogen-like activity, growth inhibition, immunoregulation, chemoprevention and antitumor activity (1). Res blocks several processes of carcinogenesis and has inhibitory effects on the initiation, promotion and development of tumors (2). However, previous studies have shown that the inhibitory effect of Res

Correspondence to: Professor Rui Yang, Department of Life Science and Technology, Xinxiang Medical University, No. 601 Jinsui Road, Xinxiang, Henan 453003, P.R. China

E-mail: ruiyang69@126.com

Key words: resveratrol, vascular endothelial growth factor, esophageal cancer on cancer cells varies between cancer types and that Res only inhibits the cell growth of certain types of cancer $(3,4)$. Res has an inhibitory effect on leukemic osteosarcoma and lung, prostate, colon, pancreatic, liver and breast cancer (5-10); however, its mechanism of action remains unknown.

Angiogenesis is one of the prerequisites of the proliferation and growth of tumor cells. During this process, vascular endothelial growth factor (VEGF) functions as the most significant vascular endothelial stimulating factor; VEGF overexpression is correlated with patient survival rate and the early relapse, infiltration and lymph node metastasis of tumors (11-13). Osteosarcoma is a malignant invasive disease which occurs among young individuals. The molecular genetics of this medical condition have been elucidated over recent years. The development of osteosarcoma is associated with simultaneous changes in multiple genes, for instance, the cooccurrence of mouse double minute 2 (MDM2) amplification and p53 deactivation promote the initiation and development of osteosarcoma (14).

In the current study, the effects of Res on osteosarcoma cell growth and VEGF expression were investigated and the mechanism of action of Res was further explored.

\section{Materials and methods}

Cell culture. The human osteosarcoma cell line U20S was cultured with $10 \%$ fetal bovine serum-containing DMEM in a $5 \% \mathrm{CO}_{2}$ incubator at $37^{\circ} \mathrm{C}$ and then digested with $0.25 \%$ trypsin for subculture.

Methyl thiazolyl tetrazolium (MTT) assay. Cells in the logarithmic growth phase at a concentration of $1.5 \times 10^{4}$ cells $/ \mathrm{ml}$ $(200 \mu \mathrm{l})$ were seeded onto a 96 -well plate for $24 \mathrm{~h}$. Res $(0,10$, 20 and $40 \mu \mathrm{mol} / \mathrm{l}$ ) with a purity of $99 \%$ (Sigma, St. Louis, MO, USA) was added, with four wells for each group. The cells were cultured for 24,48 and $72 \mathrm{~h}$, respectively. The culture medium was removed and $20 \mu \mathrm{l}$ of MTT ( $5 \mathrm{~g} / \mathrm{l})$ was added to each well for a 4 -h culture. The medium was removed and dimethyl sulfoxide was added to dissolve the crystals. The absorbance of the solution at $570 \mathrm{~nm}$ (A570 nm) was read and the cell inhibition ratio was calculated as follows: cell inhibition ratio $=[($ A570 $\mathrm{nm}$ value of the control group - A570 nm value of the experimental group)/A570 $\mathrm{nm}$ value of the control group] x $100 \%$. 
Table I. The inhibitory effect of Res on U20S cells.

\begin{tabular}{|c|c|c|c|c|c|c|}
\hline \multirow{2}{*}{$\begin{array}{l}\text { Res dose } \\
(\mu \mathrm{mol} / 1)\end{array}$} & \multicolumn{2}{|l|}{$24 \mathrm{~h}$} & \multicolumn{2}{|l|}{$48 \mathrm{~h}$} & \multicolumn{2}{|l|}{$72 \mathrm{~h}$} \\
\hline & OD570 $($ mean \pm SD $)$ & IR (\%) & OD570 $($ mean \pm SD $)$ & $\operatorname{IR}(\%)$ & OD570 $($ mean \pm SD $)$ & $\operatorname{IR}(\%)$ \\
\hline 0 & $1.2011 \pm 0.3112$ & - & $1.4407 \pm 0.2312$ & - & $1.6389 \pm 0.2234$ & - \\
\hline 10 & $1.0232 \pm 0.1503^{\mathrm{a}}$ & 3.20 & $0.7890 \pm 0.2312^{\mathrm{a}}$ & 6.71 & $0.6784 \pm 0.4321$ & 13.52 \\
\hline 20 & $0.9756 \pm 1.2724^{\mathrm{a}}$ & 23.32 & $0.6745 \pm 1.51^{\mathrm{b}}$ & 43.21 & $0.5462 \pm 0.3424^{\mathrm{a}}$ & 54.62 \\
\hline 40 & $0.7567 \pm 1.34^{\mathrm{a}}$ & 46.72 & $0.5432 \pm 1.48^{\mathrm{b}}$ & 65.08 & $0.4321 \pm 1.2613^{\mathrm{b}}$ & 87.71 \\
\hline
\end{tabular}

${ }^{\mathrm{a}} \mathrm{P}<0.01$ and ${ }^{\mathrm{b}} \mathrm{P}<0.05$, compared with the control group. Res, resveratrol; OD, optical density; IR, inhibitory rate.

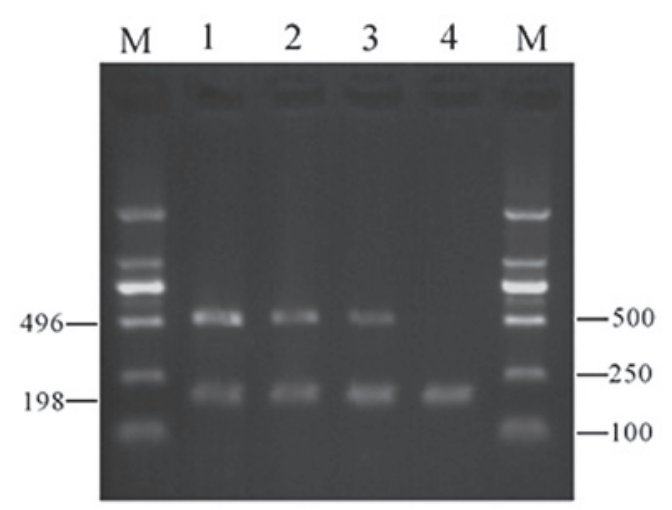

Figure 1. VEGF expression in U20S detected by RT-PCR. Lane 1, control group; lanes 2-4, 10, 20 and $40 \mu \mathrm{mol} / 1$ Res, respectively. VEGF, vascular endothelial growth factor; RT-PCR, real-time polymerase chain reaction; Res, resveratrol.

Real-time polymerase chain reaction ( $R T$ - $P C R)$. Based on GenBank (AF022375.1), the primer sequences of human VEGF were designed using the Primer 5.0 software: 5'-CAAGTGGTCCCAGGCTGCAC-3' (upstream) and 5'-CGCGAGTGTGTGTTTTTGCAGG-3' (downstream). GAPDH was taken as the internal standard and the primer sequences were as follows: 5'-AAAGTGGATATTGTTGCCATC-3' (upstream) and 5'-CAAATGAGCCCCAGCCTTCTCC-3' (downstream). Syntheses were performed by Sangon Biotech Co., Ltd. (Shanghai, China). The amplification fragment length of GAPDH was 198 bp. The concentration of the VEGF cDNA original templates was standardized according to that of the GAPDH cDNA original templates and cDNA-free wells were used for negative controls.

Total RNA was extracted with TRIzol reagent. A260 and A280 values were read on the ultraviolet spectrophotometer, RNA was qualified using agarose gel electrophoresis and the rest of the RNA was stored at $-80^{\circ} \mathrm{C}$. cDNA was reverse transcribed in line with the manufacturer's instructions (Shanghai Biology Engineering, Shanghai, China) and the products were kept at $-20^{\circ} \mathrm{C}$. The reaction system, with a volume of $30 \mu \mathrm{l}$, contained $1 \mu \mathrm{l}$ of the reverse-transcribed products, $1 \mu \mathrm{l}$ of VEGF primers, $1 \mu \mathrm{l}$ of GAPDH primers, $3 \mu \mathrm{l}$ of $10 \mathrm{X}$ bufer, $2 \mu \mathrm{l}$ of $2.5 \mathrm{mmol} / \mathrm{l} \mathrm{dNTP}$ and 2 units of Taq polymerase. The amplification conditions consisted of a pre-denaturation step at $94^{\circ} \mathrm{C}$ for $3 \mathrm{~min}, 35$ cycles of $94^{\circ} \mathrm{C}$ for $30 \mathrm{sec}, 55^{\circ} \mathrm{C}$ for $30 \mathrm{sec}$

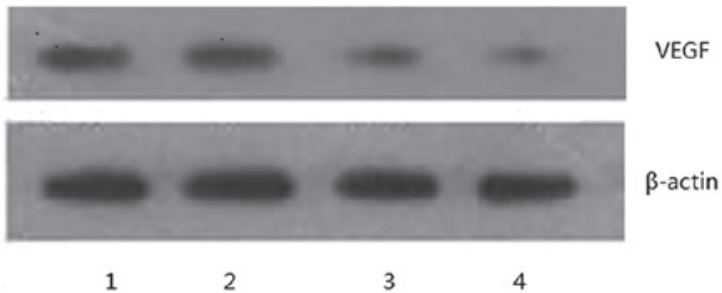

Figure 2. VEGF expression in U20S detected by western blot analysis. Lane 1, control group; lanes 2-4, 10, 20 and $40 \mu \mathrm{mol} / 1$ Res, respectively. VEGF, vascular endothelial growth factor; Res, resveratrol.

and $72^{\circ} \mathrm{C}$ for $1 \mathrm{~min}$ and a final extension step at $72^{\circ} \mathrm{C}$ for $5 \mathrm{~min}$. In the interest of quantitation, GAPDH and VEGF were amplified at the same time. The amplified products were observed following $1.5 \%$ agarose gel electrophoresis and ethidium bromide (EB) staining. Total A value (average A value $\mathrm{x}$ band area) was taken as the quantity of mRNA and VEGF mRNA expression and was then calculated based on the A value ratio between VEGF and GAPDH.

Western blot analysis. Cells in each group were collected, sonicated slightly for $10 \mathrm{sec}$ and centrifuged for total protein samples. Concentrations were determined using a Bio-Rad DC protein assay kit (Shanghai Biology Engineering). The protein sample $(50 \mathrm{~g})$ was fractionated by $12 \%$ SDS-PAGE and transferred to a polyvinylidene difluoride membrane. The membrane was treated with skimmed milk for $2 \mathrm{~h}$ and incubated with rabbit antibody against human MDM2 (1:200 dilution) at $37^{\circ} \mathrm{C}$ for $2 \mathrm{~h}$. Following washing in TBST for $30 \mathrm{~min}$, the membrane was incubated with goat anti-rabbit antibody (1:1,000 dilution) at $37^{\circ} \mathrm{C}$ for $1 \mathrm{~h}$. Following washing in TBST for $30 \mathrm{~min}$, the membrane was colored and images were captured.

Statistical analysis. Data are presented as mean \pm SD and were analyzed using the SPSS 12.0 software. $\mathrm{P}<0.05$ was considered to indicate a statistically significant difference.

\section{Results}

Inhibitory effect of Res on U20S. The MTT assays revealed that Res had an inhibitory effect on U20S at each concentration; the inhibitory effect was strengthened with the increase 
of the Res concentration as well as with the prolongation of action time, showing time- and dose-dependent characteristics (Table I).

$R T-P C R$. The purity of total RNA was assayed using the ultraviolet spectrophotometer. The results revealed that all the A260/A280 ratios fell between 1.9 and 2.0, satisfying the requirements for the experiment.

Gel electrophoresis revealed that VEGF expression in the $10 \mu \mathrm{mol} / \mathrm{l}$ Res group was significantly lower than that in the control group; in the 40- $\mu \mathrm{mol} / 1$ Res group, VEGF expression was not detected (Fig. 1). These results indicate that Res inhibits VEGF mRNA expression within a certain concentration range.

Western blot analysis. Western blot analyses demonstrated that VEGF expression in the 10- and 20- $\mu \mathrm{mol} / 1$ Res groups was significantly lower than that in the control group and no VEGF expression was detected in the $40 \mu \mathrm{mol} / 1$ Res group (Fig. 2). These results were consistent with the RT-PCR results, indicating that Res has an inhibitory effect on VEGF protein expression in U20S.

\section{Discussion}

Res is a non-flavone polyphenolic compound which is extensively present in plants and is abundant in red wines. In recent years, Res has attracted much attention from researchers and has become a hotspot in the prevention of tumors. Res inhibits tumor cell proliferation by reducing the number of G-phase cells and blocking S-phase cells (15). Res shows a bidirectional effect on the cell proliferation of prostate, breast, pancreatic and esophageal cancer, namely, a low concentration of Res promotes cell growth while a high concentration inhibits the growth (15-18).

Osteosarcoma is a primary malignant bone tumor with a strong invasive power, which occurs most commonly among young individuals. This disease is characterized by organ metastasis at an early stage and has a high relapse rate following surgery. Therefore, the study of the mechanisms of osteosarcoma invasion and metastasis, as well as other related factors, have become hot topics in the field of osteology. The proliferation, invasion and metastasis of tumor cells, as well as tumor relapse, are correlated with the interactions among multiple factors, in which angiogenesis is a prerequisite. VEGF and basic fibrolast growth factor perform significant roles in angiogenesis $(19,20)$.

In the present study, the MTT assays revealed that Res has an inhibitory effect on osteosarcoma cell proliferation and that this effect is strengthened with the increase of Res concentration as well as with the prolongation of Res action time, showing time- and dose-dependent characteristics. The RT-PCR and western blot analysis performed in this study further confirmed that Res inhibits VEGF expression within a certain concentration range in U20S cells. These results suggest that Res exerts its anti-osteosarcoma function by inhibiting VEGF expression in tumor cells.

\section{References}

1. Aggarwal BB, Bhardwj A, Aggarwal RS, Seeram NP, Shishodia S and Takada Y: Role of resveratrol in prevention and therapy of cancer: preclinical and clinical studies. Anticancer Res 24: 2783-2840, 2004.

2. Kundu JK, Chun KS, Kim SO and Surh YJ: Resveratrol inhibits phorbol ester-induced cyclooxygenase-2 expression in mouse skin: MAPKs and AP-1 as potential molecular targets. Biofactors 21: 33-39, 2004.

3. Aziz MH, Kumar R and Ahmad N: Cancer chemoprevention by resveratrol in vitro and in vivo studies and the underlying mechanisms (review). Int J Oncol 23: 17-28, 2003.

4. Jiang H,Zhang U, Kuo J, et al: Resveratrol-induced apoptotic death in human U251 glioma cells. Mol Cancer Ther 4: 554-561, 2005.

5. Wang TT, Schoene NW, Kim EK and Kim YS: Pleiotropic effects of the sirtuin inhibitor sirtinol involves concentration-dependent modulation of multiple nuclear receptor-mediated pathways in androgen-responsive prostate cancer cell LNCaP. Mol Carcinog: Apr 11, 2012 (Epub ahead of print). doi: 10.1002/mc.21906.

6. Juan ME, Alfaras I and Planas JM: Colorectal cancer chemoprevention by trans-resveratrol. Pharmacol Res 65: 584-591, 2012.

7. Liu P, Wang X, Hu C and Hu T: Inhibition of proliferation and induction of apoptosis by trimethoxyl stilbene (TMS) in a lung cancer cell line. Asian Pac J Cancer Prev 12: 2263-2269, 2011.

8. Zhou JH, Cheng HY, Yu ZQ, et al: Resveratrol induces apoptosis in pancreatic cancer cells. Chin Med J (Engl) 124: 1695-1699, 2011.

9. Yu HB, Zhang HF, Zhang X, et al: Resveratrol inhibits VEGF expression of human hepatocellular carcinoma cells through a NF-kappa B-mediated mechanism. Hepatogastroenterology 57: 1241-1246, 2010.

10. Li Y, Bäckesjö CM, Haldosén LA and Lindgren U: Resveratrol inhibits proliferation and promotes apoptosis of osteosarcoma cells. Eur J Pharmacol 609: 13-18, 2009.

11. Dvorak HF, Brown LF, Detmar M and Dvorak AM: Vascular permeability factor/vascular endothelial growth factor, microvascular hyperpermeability, and angiogenesis. Am J Pathol 146: 1029-1039, 1995.

12. Ranieri G, Patruno R, Ruggieri E, Montemurro S, Valerio $P$ and Ribatti D: Vascular endothelial growth factor (VEGF) as a target of bevacizumab in cancer: from the biology to the clinic. Curr Med Chem 13: 1845-1857, 2006.

13. Baker LC, Boult JK, Walker-Samuel S, et al: The HIF-pathway inhibitor NSC-134754 induces metabolic changes and anti-tumour activity while maintaining vascular function. Br J Cancer 106: 1638-1647, 2012.

14. Rieske P, Bartkowiak JK, Szadowska AM, Olborski B, Harezga-Bal B and Debiec-Rychter M: A comparative study of P53/MDM2 genes alterations and P53/MDM2 proteins immunoreactivity in soft-tissue sarcomas. J Exp Clin Cancer Res 18: 403-416, 1999.

15. Kim AL, Zhu Y, Zhu H, et al: Resveratrol inhibits proliferation of human epidermoid carcinoma A431 cells by modulating MEK1 and Ap-1 signalling pathways. Exp Dermatol 15: 538-546, 2006.

16. Kuwajerwala N, Cifuentes E, Gautam S, et al: Resveratrol induces prostate cancer cell entry into $\mathrm{s}$ phase and inhibits DNA synthesis. Cancer Res 62: 2488-2492, 2002.

17. Vyas S, Asmerem Y and De León DD: Resveratrol regulates insulin-like growth factor-II in breast cancer cells. Endocrinology 146: 4224-4233, 2005.

18. Golkar L, Ding XZ, Ujiki MB, et al: Resveratrol inhibits pancreatic cancer cell proliferation through transcriptional induction of macrophage inhibitory cytokine-1. J Surg Res 138: 163-169, 2007.

19. Gora-Tybor J, Blonski JZ and Robak T: Circulating vascular endothelial growth factor (VEGF) and its soluble receptors in patients with chronic lymphocytic leukemia. Eur Cytokine Netw 16: 41-46, 2005.

20. Hicklin DJ and Ellis LM: Role of the vascular endothelial growth factor pathway in tumor growth and angiogenesis. J Clin Oncol 23: 1011-1027, 2005 . 